\title{
Assessment of Groundwater Resources in the Context of Climate Change and Population Growth: Case of the Klela Basin in Southern Mali
}

\author{
Adama Toure ${ }^{1, *}$, Bernd Diekkrüger ${ }^{2}$ (D), Adama Mariko ${ }^{3}$ and Abdoulaye Salim Cissé ${ }^{4}$ \\ 1 Graduate Research Program on Climate Change and Water Resources, West African Science Service Center \\ on Climate Change and Adapted Land Use (WASCAL), Department of Applied Hydrology, \\ University of Abomey-Calavi, Cotonou, Abomey-Calavi BP 2008, Benin \\ 2 Department of Geography, University of Bonn, Bonn 53115, Germany; b.diekkrueger@uni-bonn.de \\ 3 Department of Geology, National Engineer School, Bamako BP 242, Mali; adama.mariko@ird.fr \\ 4 Department of Chemistry, University of Sciences, Techniques and Technologies of Bamako, Bamako BP 3206, \\ Mali; abdoulayesalim@yahoo.fr \\ * Correspondence: adamamca@yahoo.fr; Tel.: +223-79-43-88-36
}

Academic Editors: Nir Y. Krakauer, Tarendra Lakhankar, Ajay K. Jha, Vishnu Pandey, Pramod K. Jha and Naba R. Devkota

Received: 12 June 2017; Accepted: 27 June 2017; Published: 1 July 2017

\begin{abstract}
Groundwater in the Klela basin in Mali, a subbasin of the Bani basin (one of the main tributaries of the Niger River), is required for domestic use, irrigation and livestock. Furthermore, water supply of the city of Sikasso directly depends on the groundwater resources, which are under pressure caused by increased water demand as well as climate variability and climate change. As a consequence, freshwater availability is being threatened which can have a direct negative impact on irrigation agriculture. The aim of this study was to evaluate future behavior of groundwater resources in the context of climate change and population growth using socio-economic and population growth scenarios for water demand and the Representative Concentration Pathways scenarios (RCP4.5 and RCP8.5) data for calculating groundwater recharge using the Thornthwaite model. The WEAP (Water Evaluation and Planning system) model was applied to balance water availability and demand and to compute changes in groundwater storage up to 2050. The overall results show that groundwater recharge as well as storage is decreasing over time, especially in the 2030s which can lead to severe agricultural droughts in this period. Recharge declined by approximatively $49 \%$ and stored groundwater by $24 \%$ over the study period.
\end{abstract}

Keywords: groundwater recharge; climate change; population growth; socio-economic development; WEAP model; EARTH model; Thornthwaite model

\section{Introduction}

The Klela basin, which is a subbasin of the Bani basin, is an important area of agriculture in Mali. The main crops grown are cotton and paddy rice during the rainy season and potatoes in the dry season. Currently, the agriculture area is extending to assure food security facing growing population. Groundwater is the principal permanent water resource in the Klela basin, which is overexploited due to the agricultural and domestic water demand. Most of the population of the study area use water from traditional wells, which dry out a few days after the rainy season. It is therefore necessary to investigate current and future groundwater dynamics of this basin.

Groundwater resources are under stress all over the world. As an example, Comodi et al. [1] suggested reducing the aquifer stress by coupling thermal power plants to desalination units facing to increasing of freshwater demand mainly due to agriculture and intrusion of saltwater. Investigation 
of groundwater dynamics requires an interdisciplinary scope and that involves the application of the physical, biological and mathematical sciences [2]. Groundwater dynamic simulation is one of the most complex of the sciences [2]. Many studies have already discussed the challenges that the Bani and its tributaries are facing, which will result in a significant decrease of the groundwater table. For example, the study carried out by Mahé et al. [3] has been concluded that during the periods of rainfall deficit (especially 1981-1995), the groundwater table at the level of Bani at Douna was significantly reduced. In parallel to these studies, Bricquet et al. [4] showed a reduction of groundwater storage of the Bani basin due to a decrease in rainfall and runoff. In addition, the Klela region was rated by Roudier and Mahé [5] as a region threatened by climate change. Because of all these threats, there is a need to develop a scientific tool to simulate the present and future behavior of groundwater dynamics. The study performed by Toure et al. [6] has analyzed the groundwater dynamics of the Klela basin using PMWIN (Processing MODFLOW for Windows). Other methods were applied throughout the world to quantify groundwater dynamic. For example, Cervi et al. and Mussi et al. $[7,8]$ have used isotope data to characterize the aquifer recharge and water movement in Italy. In addition, Aquilanti et al. [9] applied artificial tracer techniques to study the groundwater dynamics and characterize the flow parameters. Socio-economic and population growth scenarios have not yet been used together with climate scenarios to compute future groundwater demand and availability. This study is focusing on future groundwater dynamics in the context of climate change as well as socio-economic and population development. The aim is to differentiate between the different drivers of development and to identify the most important factor influencing future groundwater availability. Identifying the key factors supports sustainable water resources managements and the identification of adaptation strategies.

\section{Study Area}

The Klela basin, almost entirely located in southern Mali in the Sikasso region, is situated at $5^{\circ} 55^{\prime} 58.8^{\prime \prime}$ and $5^{\circ} 16^{\prime} 12^{\prime \prime}$ longitude and $11^{\circ} 40^{\prime} 58.8^{\prime \prime}$ and $10^{\circ} 59^{\prime} 45.6^{\prime \prime}$ latitude and covers a surface area of approximatively $3680 \mathrm{~km}^{2}$ (Figure 1). The main surface water that drains the Klela area is the Lotio, one of the tributary rivers of the Bani, which flows periodically. All inhabitants of the basin depend directly or indirectly on groundwater resources, the only assured water supply. The topography of the study area is accentuated by a sandstone plateau. The elevation of the basin ranged from great "bas-fonds" to the sandstone plateau with elevation varying from $305 \mathrm{~m}$ amsl in the north of the basin at Klela to $750 \mathrm{~m}$ amsl in the south towards Burkina Faso. The geology of the Klela basin, which belongs to Tabular Infra-Cambrian, is mainly composed of sandstone and dolerite formations. Nonetheless, the fractured sandstone formation is the main geologic unit. In the fractured bedrock, groundwater resources can be reached at depths of up to $100 \mathrm{~m}$ [6]. Covering sandstone bedrock are the recent formations that are composed by clay, sand and laterite, with a maximum covering thickness of $64 \mathrm{~m} \mathrm{[6]}$. "The minimum monthly temperature varies from $12.3^{\circ} \mathrm{C}$ to $26.8^{\circ} \mathrm{C}$, the maximum temperature ranges from $28.8^{\circ} \mathrm{C}$ to $39.9^{\circ} \mathrm{C}$ and the average temperature is $27.4{ }^{\circ} \mathrm{C}$. The climate belongs to the Soudano-Sahelian zone and is characterized by a dry season (November-May) dominated by a dry wind from the Sahara (Harmattan) and a rainy season (June-October) with a wet wind from the Guinean Gulf (monsoon) [10]. The mean annual precipitation is approximately $1131 \mathrm{~mm} /$ year. The average annual potential evapotranspiration is approximately $2060 \mathrm{~mm} /$ year based on the Blaney-Criddle method" [6]. 


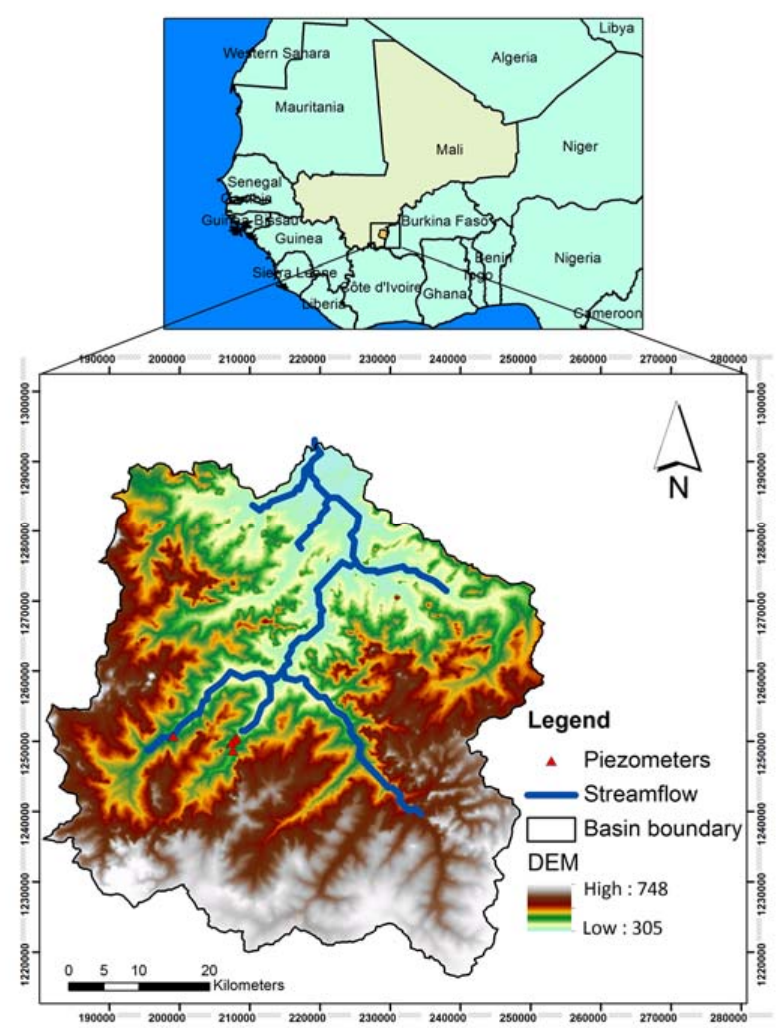

Figure 1. Geographical location of the Klela basin in southern Mali (Toure et al. [6]).

\section{Materials and Methods}

\subsection{Thornthwaite Model}

Before simulating groundwater dynamics using WEAP, groundwater recharge has to be computed, and this is one of the important input for this model. The Thornthwaite model [11], developed by the U.S. Geological Survey, was applied for this purpose, which uses monthly total precipitation (in millimeters) and temperature (in degrees Celsius) as inputs to estimate groundwater recharge. The Thornthwaite model is based on a monthly water-balance model that is driven by a graphical user interface.

The water-balance model calculates the water amount of the various components of the hydrological cycle (Figure 2) using a monthly accounting procedure [11]. Seven input parameters (runoff factor, direct runoff factor, soil-moisture storage capacity, the latitude of the location, rain temperature threshold, snow temperature threshold, and maximum snow-melt rate of the snow storage), incorporated in the model, were adapted during the model calibration process. The model was calibrated to fit the groundwater recharge previously simulated by Toure et al. [6], using EARTH (Extended model for Aquifer Recharge and soil moisture Transport through the unsaturated Hardrock) model. To calibrate this model, monthly precipitation and temperature from RCP4.5 and RCP8.5, from 2012 to 2013 were used as input data, direct runoff was set to zero because local scale surface runoff infiltrates on the way to the river system. There is no direct runoff contribution to the discharge of the basin. The soil moisture storage capacity was calibrated to be $375 \mathrm{~mm}$ by comparing the groundwater recharge of the two models (EARTH and Thornthwaite). All other parameters were unchanged. More detail on this model can be found in [11]. After calibration, the model was applied to simulate groundwater recharge [6] from 2006 to 2050, as well as potential evapotranspiration, actual evapotranspiration, soil moisture storage and runoff. 


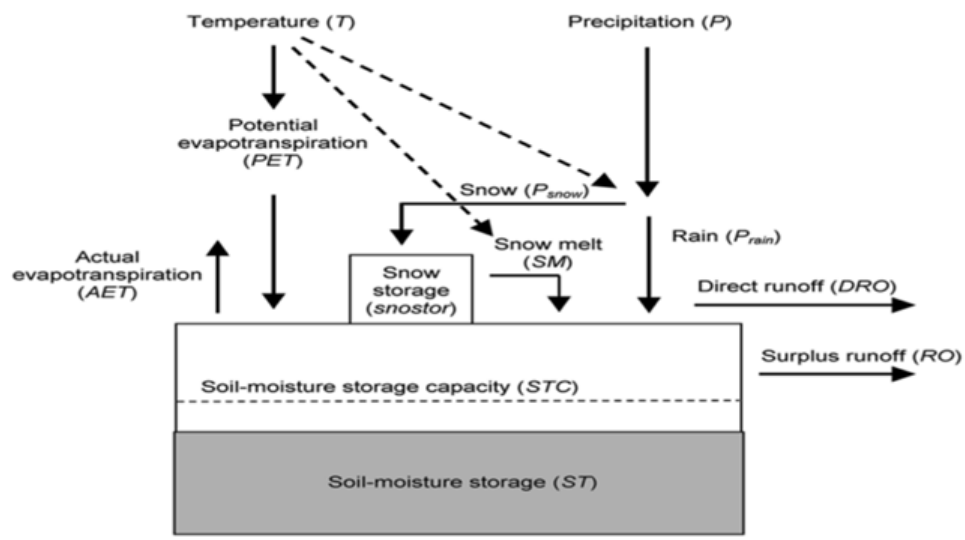

Figure 2. Diagram of the Thornthwaite water-balance model (adapted from [11]).

\subsection{WEAP (Water Evaluation and Planning System) Model}

WEAP is a software tool developed by the Stockholm Environment Institute for integrated water resources planning and as an integrated decision support system (DSS), that is aimed to support water planning system by comparing water supplies generated [12] from surface water (e.g., streamflow, lake, seepage, spring, etc.) and groundwater (e.g., natural and artificial recharge) of a basin scale, or municipal scale, and "multiple water demands and environmental requirements characterized by spatially and temporally variable allocation priorities, and supply preferences" [13,14]. According to Haddad et al. [15], the DSS for a water resources management system involve three major components (1) stakeholders survey to define key planning issues; (2) database system to facilitate data management; and (3) the WEAP model that simulates and predicts water resources using multiple alternative scenarios. It is straightforward and easy to use, free of charge for organizations and institutions in developing countries and downloadable at: www.weap21.org.

The WEAP model can be used to simulate both natural hydrological processes and anthropogenic effects on natural water resources to assess water availability within the basin and the human impact on water use respectively [14-16]. The simulations within the WEAP model "are constructed as a set of scenarios using monthly time steps with a time horizon of a single year to more than 100 years" [14].

In WEAP, the future behavior of water availability and demand is compared to the current or a baseline year, which is based on a snapshot of actual water demand and supplies, known as Current Accounts. Basically, the baseline year is chosen to determine the recent water availability of a system; and then, to evaluate the impact of different alternative scenarios for the future. Generally, the baseline year is the year where enough information on all input data such as hydrology, precipitation, natural infiltration, temperature, demography, socio-economic, agriculture, etc. is available. The adaptability of the WEAP model to various levels of data availability and its simple graphical user interface make it an appropriate tool to be used under all climatic conditions [17] including Klela basin case, where data availability is very low. WEAP has been chosen in this study to assess the impact of human actions and the impact of climate change effects on the groundwater resources, by developing multiple alternative scenarios for socio-economic development, population growth, and climate.

The WEAP model is fundamentally based on water balance accounting principle and can be applied to community and agricultural systems, single subbasin or complex transboundary river systems $[18,19]$. It may "address a wide range of issues; for instance, sectoral demand analyses, water conservation, water rights and allocation priorities, groundwater and streamflow simulations" [14].

The modeling process within WEAP follows three steps: (i) creation of a geographic representation of the study area on which all the features (supply and demand sites) are represented, (ii) establishment of the current account; this involves choosing a reference year (baseline) in which all or the maximum of data are available. In this part, the reference scenario is created which shows the probable evolution of the system during the simulation period without any modification (business as usual scenario), and 
(iii) development and evaluating of model scenarios which is the most important part of modeling allowing predicting an eventual change of water resources by answering a wide range of questions. For example, what happens when demographic or economic patterns change? What happens when the mix of agricultural crops changes? What happens when groundwater is more exploited? How does climate change alter demand and supplies? In any case, the general question is how the groundwater resources in the Klela basin will develop under population growth and climate change?

The schematic view is a spatial physical feature of the water supply and demand system. It permits to connect all supply and demands by using nodes and transmission links. The schematic of the Klela basin is shown in Figure 3. Red points in this figure represent water demands in the study area. These water demands include irrigation, industry, livestock, rural and urban, which explain the quantity of water use in each sector; urban and rural indicate domestic water use. The green square is groundwater source, which furnishes water to other sectors via a transmission link, in the green arrow.

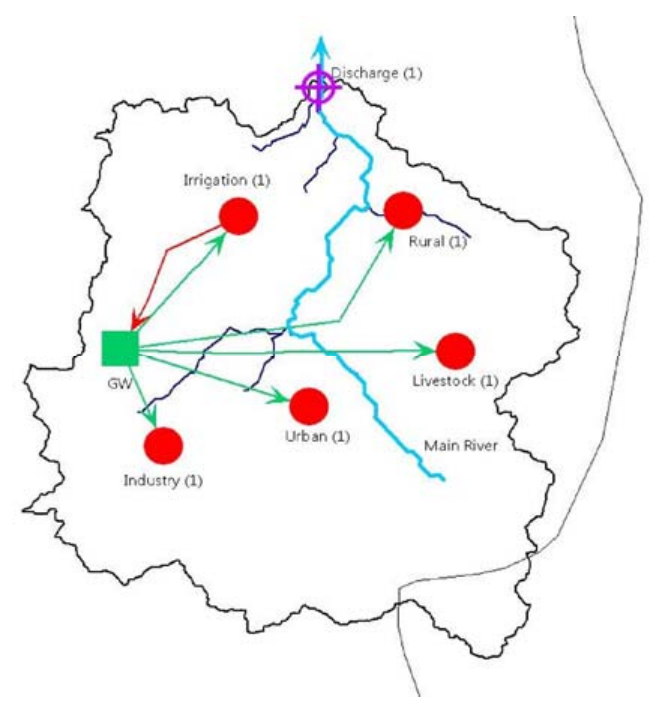

Figure 3. Schematic of the WEAP model for the Klela basin, GW is groundwater. Red points are water demands; the green square is groundwater source, the green and red arrows are the transmission link (which link water sources and sinks); and the symbol is the discharge point of the study area.

\subsubsection{Development of Scenarios}

According to the last census in Mali [20], the average population growth rate was estimated to be 3.6\%, and it is increasing from one census to another. Moreover, Traore and Sissoko [21] argued that the population of Mali could be doubled in 2050 but the projection made by DAES, cited in [21], suggested that the growth rate will decrease from 2010 and will reach 1.43\% between 2045 and 2050 . Besides population growth, the increasing trend of urbanization rate is also noticeable in Mali. In 1998, urbanization rate was approximatively $27 \%$, and it was estimated to exceed $40 \%$ in 2015 (PNUD cited in [22]). All these (population growth and urbanization evolution) increase the water demand for the population.

What are the implications for the groundwater resources facing this pressure of population growth? The question comprises various variables including the closeness and accessibility of groundwater resources, groundwater system vulnerability, the consistency and comprehensiveness of existing governance regimes, type of current stresses, and climate change impacts.

The same growth rate (3.6\% for the whole Mali) was considered in the Klela basin. The population of the Klela basin is estimated to be 462,544 in 2009, calculated to be 532,834 in 2013 (baseline for the model), and will reach 1,971,982 in 2050 assuming a constant growth rate.

In this study, climate data series (past and future) were taken from the General Circulation Model (GCM) ECHAM downscaled to a $0.44^{\circ}$ (approximatively $50 \mathrm{~km}$ ) resolution by the Swedish 
Meteorological and Hydrological Institute (Sveriges Meteorologiska och Hydrologiska Institute, SMHI), and furnished by the CORDEX (Coordinated Regional Climate Downscaling Experiment) initiative. These data are used to assess the impacts of climate change on groundwater resources in the Klela basin. CORDEX is a program funded by World Climate Research Programme (WCRP) of which the main aim is to develop a framework allowing the use of downscaled global climate projections and assessing regional climate downscaling techniques and finally using them into impact and adaptation studies within the IPCC Fifth Assessment Report (AR5) timeline [23]. CORDEX domains cover most of the land surfaces of the world. Based on regional focus and improved resolution, "it is anticipated that the CORDEX dataset will provide a link to the impacts and adaptation community" [24]. CORDEX is focused on the GCM experiments applying emission scenarios that are based on Representative Concentration Pathways (RCPs). The RCPs "are four greenhouse gas concentration trajectories adopted by IPCC for its fifth assessment report in 2014", which replace the Special Report Emission Scenarios projections in 2000 [25]. The RCPs describe an emission trajectory and concentration by the year 2100, unlike SRES that starts by socio-economic from which emission trajectories and climate impacts are projected [25]. A set of four pathways were created based on radiative forcing degrees of 8.5, 6, 4.5 and $2.6 \mathrm{~W} / \mathrm{m}^{2}$ corresponding to RCP8.5, RCP6, RCP4.5 and RCP2.6, respectively, by the end of 2100. Only the two scenarios (RCP4.5 and RCP8.5) were taken into account in this case study and are described below. The RCPs dataset cover the period 1950-2100 [26].

- RCP4.5: the scenario RCP4.5 is an intermediate pathway that is around the stabilization level of approximatively $4.5 \mathrm{~W} / \mathrm{m}^{2}$ [27], supposing that all the world countries undertake emission mitigation policies [28]. Comparing RCP4.5 with the GCAM (General Circulation Atmospheric Model) reference scenario, it has been demonstrated in [28] that the population and income drivers are the same, but they are different from the policy applied to "greenhouse gas emissions to stabilize atmospheric radiative forcing". The main anthropogenic gas emission for RCP4.5 is carbon dioxide $\left(\mathrm{CO}_{2}\right)$ and comprises the widest contribution to total radiative forcing followed by methane $\left(\mathrm{CH}_{4}\right)$ and others [28]. In order to decrease greenhouse gas emissions in the atmosphere and stabilize radiative forcing by 2100 , the RCP4.5 scenario is projected to inform research on the atmospheric consequences [28]. Refer to [28] for more details.

- $\quad$ RCP8.5: The worst case scenario RCP8.5 is a reference scenario and representing the highest RCP scenario regarding GHG emissions without any explicit climate policy. "RCP8.5 is a rising radiative forcing pathway leading to $8.5 \mathrm{~W} / \mathrm{m}^{2}$ in $2100^{\prime \prime}$ [29]. In RCP8.5, increasing global population (approximatively 12 billion by 2100) and economy associated with a lower rate of technology development lead to increasing primary energy demand [30]. An increasing global population in RCP8.5 is mostly due to increasing use of cropland and grasslands [26]. It is mentioned in Riahi et al. [30] that in RCP8.5 the greenhouse gas emissions continue rising due to mainly the high intensity of fossil energy as well as growing population and also high demand for food [30]. Most of the GHG emissions rising are due to those of $\mathrm{CO}_{2}$ from energy sector; but from agriculture sector, it is principally attributed "to increasing use of fertilizers and intensification of agricultural production, giving rise to the main source of nitrogen dioxide $\left(\mathrm{N}_{2} \mathrm{O}\right)$ emissions" [30]. Besides the principal gases responsible for radiative forcing such as $\mathrm{CO}_{2}, \mathrm{CH}_{4}, \mathrm{NO}_{2}$, etc., there are some others additional tropospheric ozone in RCP8.5, which are "expected to increase the radiative forcing by an additional $0.2 \mathrm{~W} / \mathrm{m}^{2}$ by $2100^{\prime \prime}$ [31].

In this study, the scenarios have been developed for the time interval 2013-2050, with the year 2013, the current account (baseline). The baseline (2013) was chosen based on the availability of consistent and reliable data. Six scenarios were developed such as:

1. Reference scenario: it refers to the current account scenario in which the socio-economic is used (business as usual). Climate (precipitation) data is based on current account year (2013). Therefore, the recharge was constant over time from 2013-2050. 
2. High population growth scenario: the present growth rate (3.6\%) will increase by $2 \%$ to become $5.6 \%$ in 2050. Other parameters are used as reference scenario.

3. Socio-economic scenario E1: all water demand data is moderately increasing, except livestock which is the same as in reference scenario, and population growth decreases (based on DAES projection, see before) slightly compared to the reference scenario.

4. Socio-economic scenario E2: high water demand scenario with slight decrease of population growth, but greater than in scenario E1. All socio-economic data are increased to cover the possible future water demand.

5. Climate change scenario using RCP4.5: only the climate data from the RCP4.5 scenario was used. The population and other demands were not changed.

6. Climate change scenario using RCP8.5: only the climate from the RCP8.5 scenario was used. The other parameters were used as in the reference scenario.

The raw climate data from CORDEX were used directly to the model without any bias correction because its historical mean datasets of precipitation and temperature were nearly fitted to the observed dataset measured from the field (Figures 4 and 5). Figure 4 compares the mean monthly precipitation from measurements to that from CORDEX, and the correlation coefficient is greater than 0.5 , which reveals an acceptable relation between both. In addition, the correlation coefficient of 0.802 for temperature shows a good correlation between observed measurements and simulated from CORDEX (Figure 5)

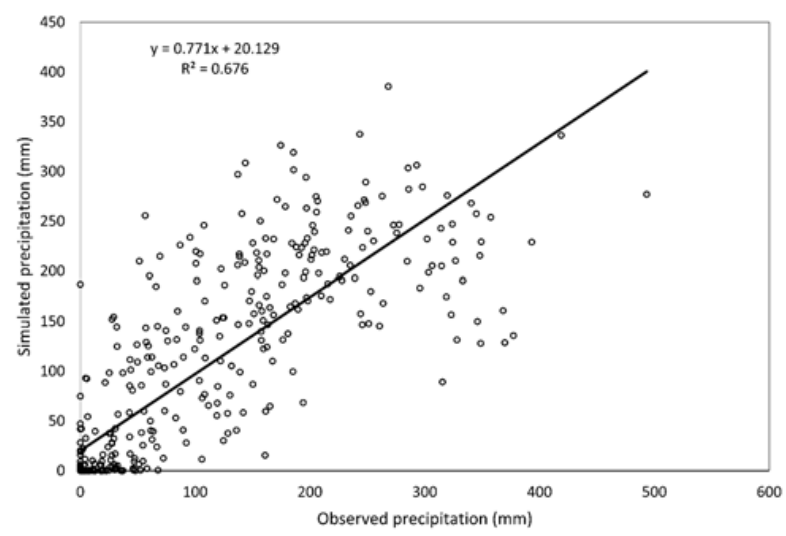

Figure 4. Mean monthly precipitation $(\mathrm{mm})$ between observed and simulated by SMHI-ECHAM (1970-2005).

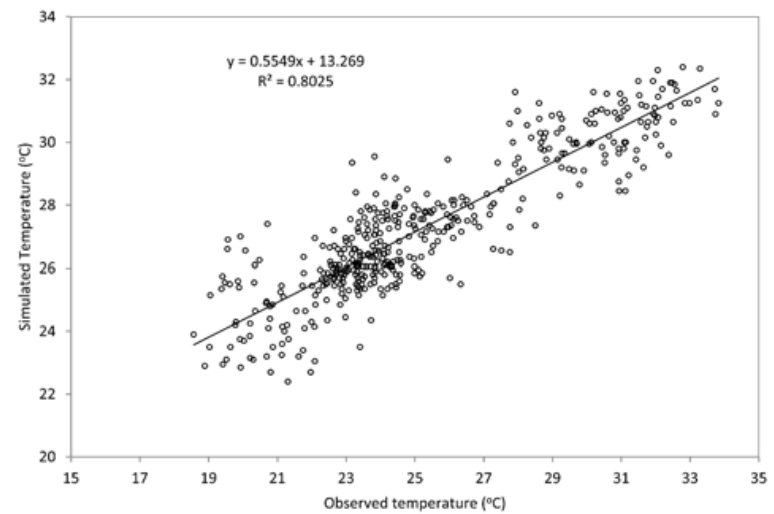

Figure 5. Comparison between observed and simulated temperature $\left({ }^{\circ} \mathrm{C}\right)$ by SMHI-ECHAM (1970-2005). 


\subsubsection{Water Supply Resources}

The main source of water in the Klela basin is groundwater, which is accessed through wells and boreholes. These groundwater sources are principally replenished by local precipitation through the infiltration. This infiltration has been estimated by Toure et al. [6] using the EARTH model to be approximatively $13.9 \%$ of mean annual precipitation. The precipitation data from DNM for the current account (the year 2013) and from SMHI-ECHAM for the scenarios (2014-2050) were used in this study.

Other water sources which are seasonally important are stream flows. These resources are notably used for irrigation and livestock.

\subsubsection{Water Demands}

Four types of water users are known in the Klela catchment: households, irrigation, industry, and livestock. Water demand per person in Mali depends strongly on the state of urbanization, which is in turn based on the number of inhabitants per region. For example, in the village (with less than 2000 inhabitants) the water demand is 20 liter per capita per day (lpcpd) [32,33] while it is 31 lpcpd in semi-urban areas (between 2000-10,000 inhabitants) and in urban areas (greater than 10,000 inhabitants) it is 45 lpcpd [32-34]. Since most of the population in the Klela basin is living in the villages, 20 lpcpd has been used as their water demand. The remainder of the population living in town receives water via SOMAGEP (Société Malienne de Gestion de l'Eau Potable). During the rainy season, the rivers contribute to satisfying water demand in rice irrigation and livestock water need.

The population data was used to estimate the domestic annual water use. The data for irrigation was provided by DRGR Sikasso (Direction Régionale du Génie Rural de Sikasso) and PCDA (Projet pour la Competitivite et Diversion Agricole). In fact, two major types of crops (rice and potato) that consume a huge quantity of water were used to compute irrigation water demand. There are other types of crops, but data are not available and the quantity of water used is small compared to rice and potato. Rice cultivation is carried out during the rainy season from June to October. Potato is irrigated in the dry season from November to February. Groundwater is the principal source exploited for this need [35]. This source is extracted from wells manually or through motor pumps depending on the extension of the irrigated surface. The industry is not well developed in this rural study area, as there are only some few small factories that withdraw water from groundwater (source DRI: Direction Regionale d'Industrie). The statistical details on the current situation in 2013 are given in the Table 1. The details concerning the water demands are shown in Table 2.

Table 1. Statistics information on current situation (2013).

\begin{tabular}{cccccccc}
\hline \multicolumn{2}{c}{ Population } & \multicolumn{2}{c}{ Demand per Capita $\left(\mathbf{m}^{3} /\right.$ Year) } & \multicolumn{2}{c}{ Irrigation (ha) } & Livestock & Number of Factories \\
\hline Urban & Rural & Urban & Rural & Potato & Rice & & \\
260,059 & 272,775 & 15 & 7.5 & 576 & 4612.2 & 363,270 & 12 \\
\hline
\end{tabular}

Table 2. Water demand data for current account for the year 2013 in million cubic meters $\left(\mathrm{Mm}^{3}\right)$.

\begin{tabular}{llcl}
\hline \multicolumn{2}{c}{ Demand Site } & Annual Water Demand $\mathbf{( M m}^{\mathbf{3}} \mathbf{)}$ & \multicolumn{1}{c}{ Reference } \\
\hline Domestic & Urban & 3.90 & $\begin{array}{l}\text { DNSI (La Direction Nationale de la Statistique et de } \\
\text { l'Informatique), RGPH (Recensement Général de la } \\
\text { Population et de l'Habitat) } \\
{[34]}\end{array}$ \\
\hline Livestock & Rural & 2.05 & DRSV (Direction Régionale des Services Vétérinaires) \\
\hline Irrigation & Rice & 3.31 & $\begin{array}{l}\text { DRGR (Direction Régionale du Génie Rural) } \\
\text { Diakité and Zida [35], PCDA (Projet pour la } \\
\text { Compétitivité et Diversion Agricole), Fiche } \\
\text { technique pomme de terre }\end{array}$ \\
\hline Industry & Potato & 4.49 & DRI (Direction Régionale de l'Industrie) \\
\hline Total & 0.05 & \\
\hline
\end{tabular}




\section{Results and Discussion}

The Thornthwaite model was used to estimate the recharge for the RCP4.5 and RCP8.5 scenarios as explained before. The results show that in both scenarios groundwater recharge is decreasing more under RCP8.5 than under RCP4.5. In the 2030s drought events are simulated to be severe especially from 2033 to 2037 for both climate scenarios (Figure 6) resulting in a mean annual precipitation for RCP8.5 (960 mm, see Figure 6b) which is lower than that for RCP4.5 (1006 mm, see Figure 6a). As shown in Figure 4, groundwater recharge computed by the Thornthwaite model directly depends on precipitation. In general, the recharge is zero or close to zero when the total annual precipitation is less than the long-term mean annual precipitation. A small percentage change in precipitation can reduce recharge to zero. This calculated recharge was used as input to the WEAP model.

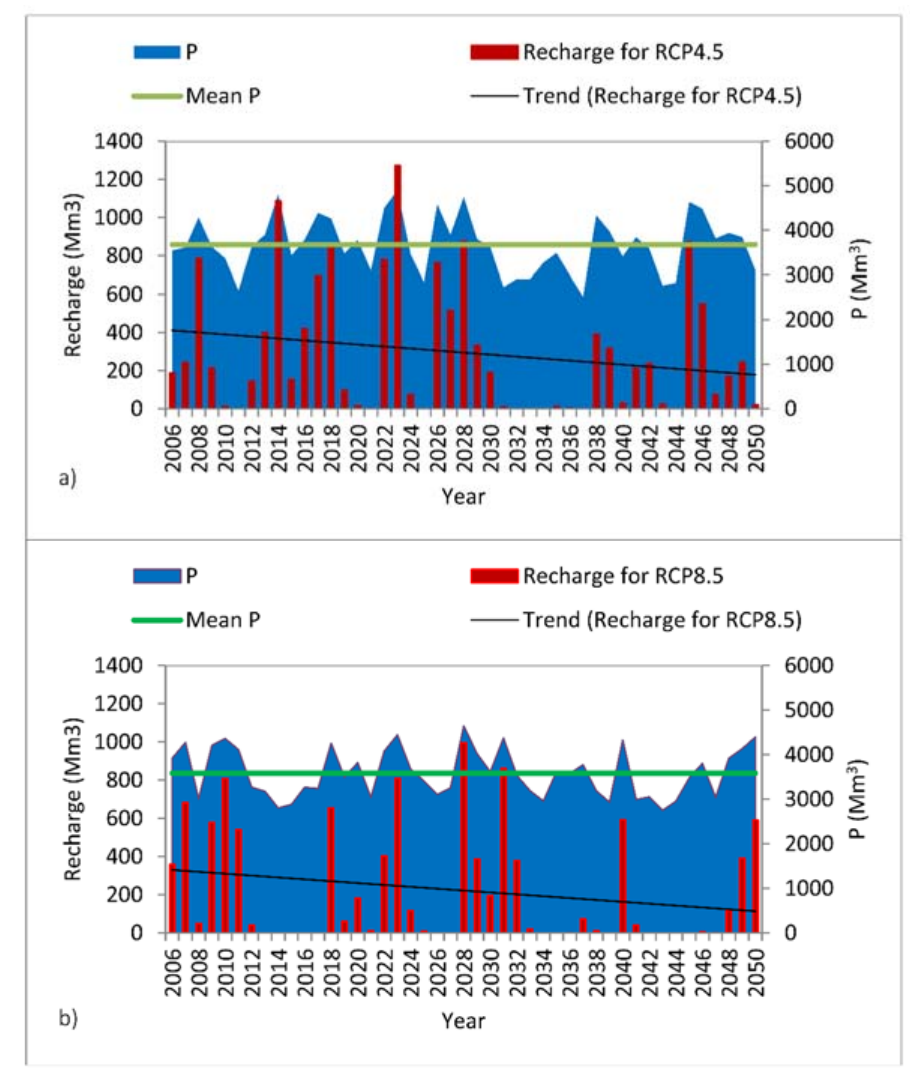

Figure 6. Estimated recharge $\left(\mathrm{Mm}^{3}\right)$ and annual precipitation $\left(\mathrm{Mm}^{3}\right)$ for scenarios (a) RCP4.5 and (b) RCP8.5 in the Klela basin from 2006-2050. The lines are linear regressions of trends in recharge and mean annual precipitation against time.

Table 3 gives details on the mean annual (from 2006-2050) output parameters from the Thornthwaite model calibration. The annual PET is greater than the annual precipitation in the study area.

Table 3. Mean annual value $(\mathrm{mm})$ of output parameters from Thornthwaite model. PET: Potential Evapotranspiration (mm); P: Precipitation; AET: Actual Evapotranspiration (mm) from 2006-2050.

\begin{tabular}{ccccc}
\hline Scenarios & PET & P & AET & Recharge \\
\hline RCP4.5 & 1372.8 & 999.2 & 919.3 & 80.2 \\
RCP8.5 & 1391.7 & 974.2 & 913.3 & 60.2 \\
\hline
\end{tabular}


The water demand for the Klela basin regarding different human activities was estimated to be about 76 million cubic meters for the current account year, 2013. From this current year, the reference, socio-economic, and population growth scenarios were developed to compute the future water demand.

Water demand was computed considering all scenarios described before and all sectors of water use (irrigation, domestic, livestock, and industry) starting from the baseline year 2013 up to the end of the year 2050 .

The annual water demands can be seen in Figure 7, where the demand increases considerably over time for all the scenarios. However, scenario E2 requires more water than others, and the demand reaches approximately $224 \mathrm{Mm}^{3}$ in 2050 . Scenario E1 and the high population growth scenario are close to each other in terms of water demand because they represent the moderate water demand, but demand is higher in scenario E1 than that in the population growth scenario.

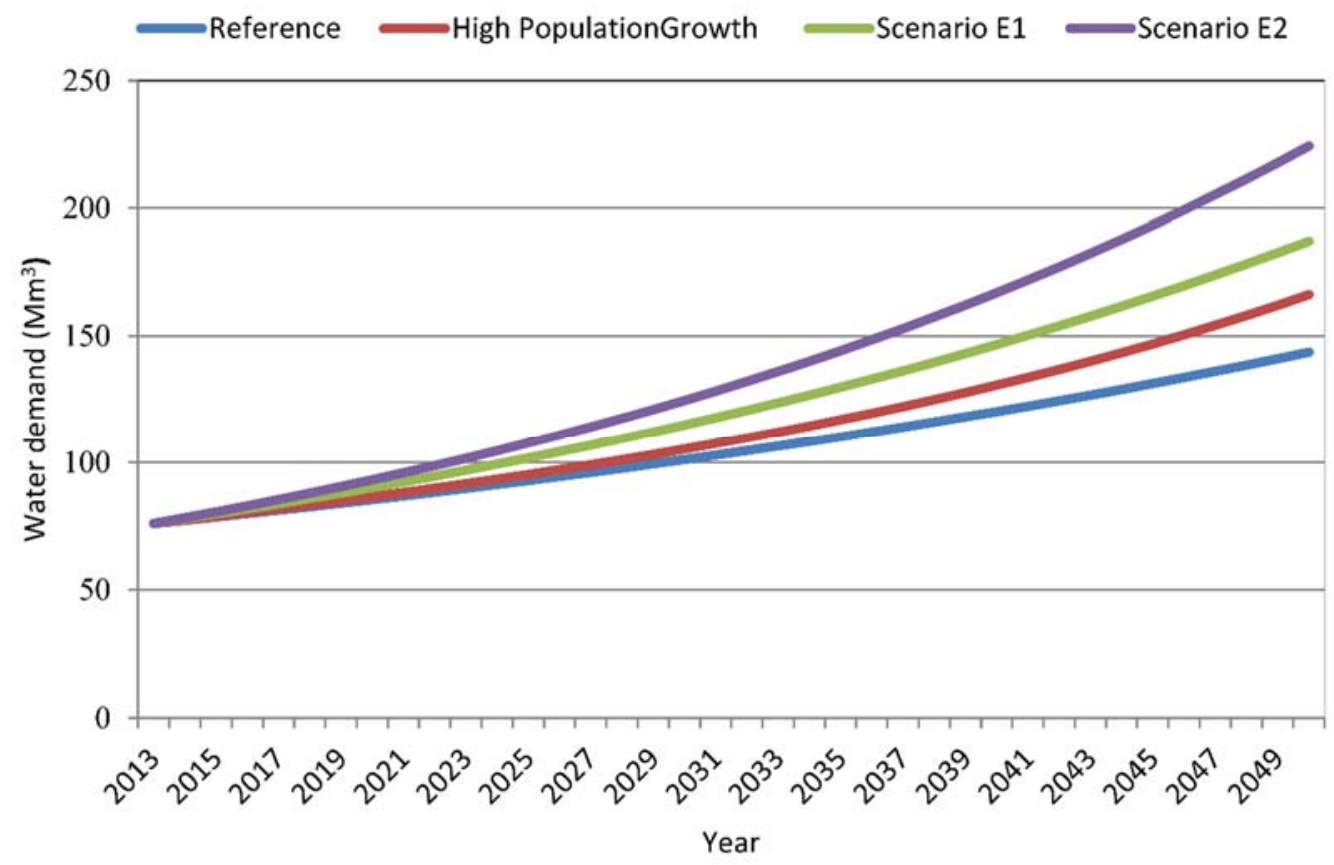

Figure 7. Annual water demand in million cubic meters for the scenarios reference (business as usual), high population growth and socio-economic development from 2013-2050 assuming a constant climate.

The model WEAP was applied to calculate the water demand per sector as shown in Figure 8. Water demand for irrigation is much higher than for domestic use. The annual water demand for irrigation reaches $199 \mathrm{Mm}^{3}$ in 2050 in scenario E2. Water demand for livestock was set as constant over time for all scenarios because industrial development in an area may reduce the activities of animal husbandry in this zone. Water demand for domestic activities is also important, however, it is higher in urban than in rural areas. In the population growth scenario, the domestic water use is larger in the future due to the increase in the population growth in the study area. Presently, the industry is poorly developed in the study area, but it is expected to increase in future due to the rapid increase of urbanization and agriculture. Therefore, the water use for the industry in scenario E2 was consequently increased in the future. 


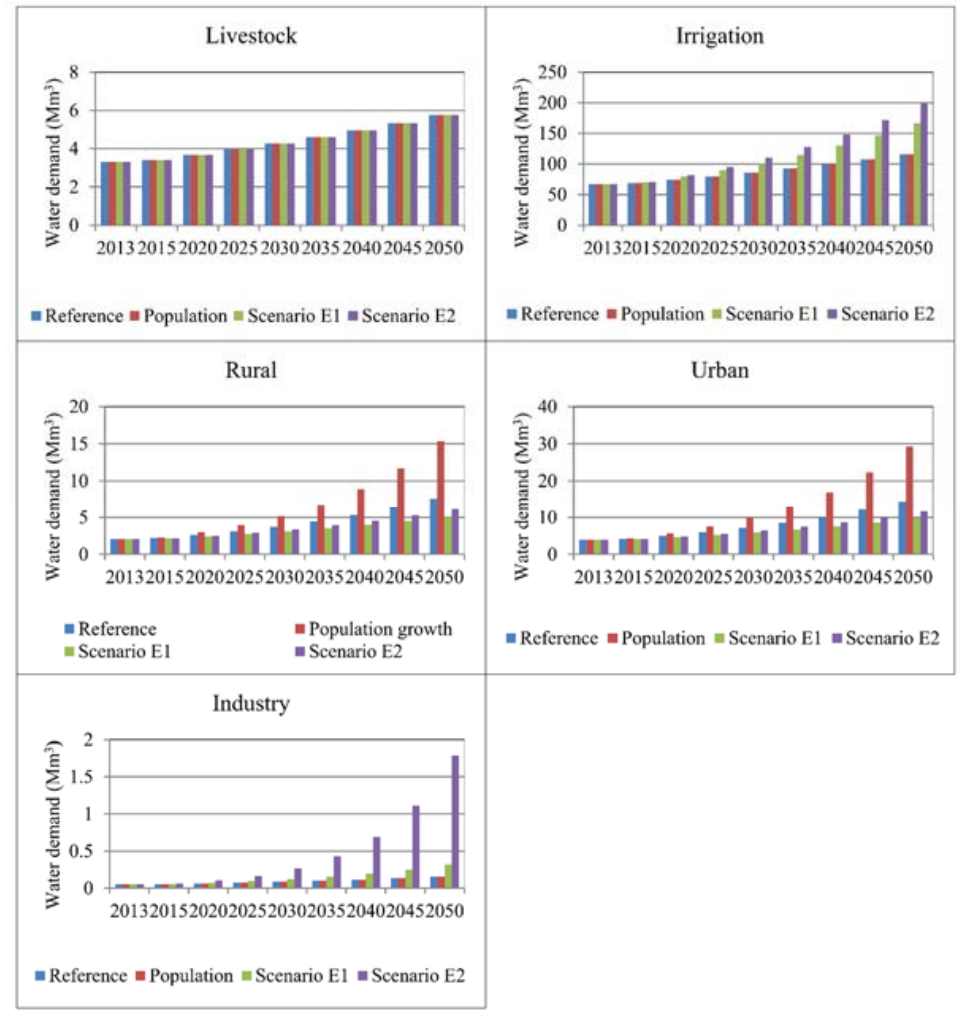

Figure 8. Water demand per sector in million cubic meters for three scenarios reference, scenario E1 (medium economic growth), and scenario E2 (high economic growth).

\section{Hydrology}

The WEAP model was able to estimate the components of the hydrologic system, i.e., the inflow and outflow of the groundwater (Table 4). The hydrological model results show a five year time steps variation between groundwater inflows and outflows in both scenarios. However, an extreme drought occurs in the RCP4.5 scenario, where groundwater recharge is nearly zero from 2031 to 2035 (Table 4).

Table 4. Annual precipitation, groundwater recharge and outflows in billion cubic meters $\left(10^{9} \mathrm{~m}^{3}\right)$ for the current account and climate change scenarios RCP4.5 and RCP8.5 for the Klela basin.

\begin{tabular}{|c|c|c|c|c|}
\hline Climate & Interval of Years & Recharge $\left(10^{9} \mathrm{~m}^{3}\right)$ & Precipitation $\left(10^{9} \mathrm{~m}^{3}\right)$ & GW Outflow $\left(10^{9} \mathrm{~m}^{3}\right)$ \\
\hline Current account & 2013 & 0.52 & 4.65 & 0.44 \\
\hline \multirow{8}{*}{ Scenario RCP4.5 } & $2013-2015$ * & 0.59 & 4.05 & 0.45 \\
\hline & 2016-2020 & 0.41 & 3.94 & 0.45 \\
\hline & $2021-2025$ & 0.43 & 3.76 & 0.41 \\
\hline & $2026-2030$ & 0.54 & 4.13 & 0.41 \\
\hline & 2031-2035 & 0.00 & 3.06 & 0.33 \\
\hline & 2036-2040 & 0.15 & 3.45 & 0.23 \\
\hline & $2041-2045$ & 0.27 & 3.53 & 0.18 \\
\hline & $2046-2050$ & 0.21 & 3.84 & 0.18 \\
\hline \multirow{8}{*}{ Scenario RCP8.5 } & $2013-2015$ * & 0.17 & 2.95 & 0.43 \\
\hline & 2016-2020 & 0.18 & 3.61 & 0.34 \\
\hline & $2021-2025$ & 0.27 & 3.73 & 0.29 \\
\hline & $2026-2030$ & 0.32 & 3.73 & 0.25 \\
\hline & 2031-2035 & 0.25 & 3.53 & 0.27 \\
\hline & $2036-2040$ & 0.14 & 3.56 & 0.18 \\
\hline & $2041-2045$ & 0.01 & 3.04 & 0.13 \\
\hline & $2046-2050$ & 0.22 & 3.86 & 0.07 \\
\hline
\end{tabular}

* The first period for scenarios is different from the others by its length, which is only three years. 
The comparison between the precipitation and groundwater dynamics can be seen in the Figure 9. For both scenarios, the groundwater dynamic has a decreasing trend, but more significant in the climate scenario RCP8.5. The important reducting of the groundwater dynamic for the scenario RCP4.5 is recorded in the period from 2031 to 2035, approximatively $35 \%$ of groundwater dynamic rate of the current account year (Table 4 and Figure 9). In scenario RCP8.5, the groundwater dynamic from the period 2041 to 2045 is approximatively 15\% of the amount of the current account year.

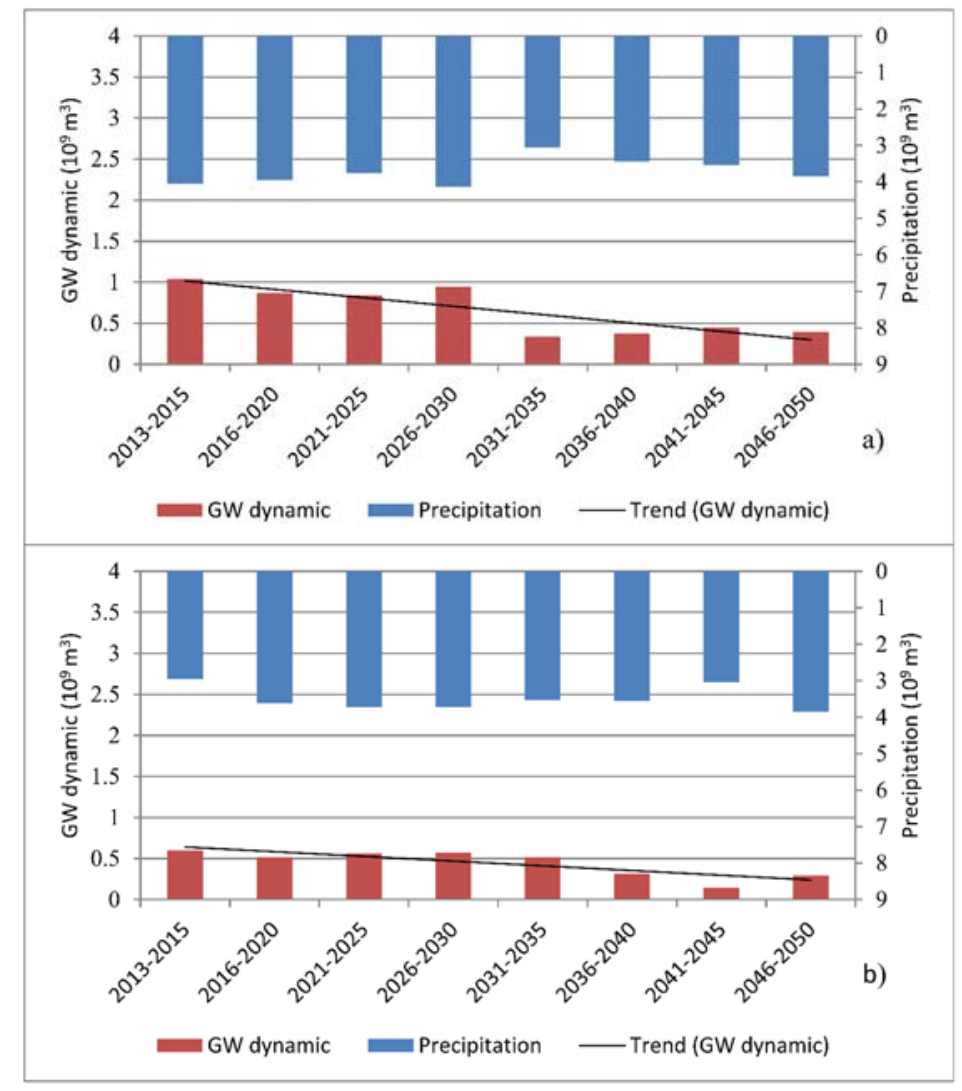

Figure 9. Comparison between precipitation and groundwater dynamic (groundwater recharge + groundwater outflow) in billion cubic meters $\left(10^{9} \mathrm{~m}^{3}\right)$ in the Klela basin for the climate scenarios (a) RCP4.5 and (b) RCP8.5. The lines are linear regressions of trends in groundwater dynamic against time.

In order to model long-term groundwater storage, groundwater storage in equilibrium was firstly calculated, which was estimated to be 4.6 billion cubic meters $\left(\mathrm{km}^{3}\right)$. The initial groundwater storage was estimated to be about $11 \mathrm{~km}^{3}$. The results shown in Figure 10 reveal that the groundwater storage is decreasing over time for all scenarios. The lowest groundwater storage occurred in July (end of dry season), while the highest is recorded in October (end of rainy season) for the reference, population growth, socio-economic E1 and E2 scenarios (Figure 10a). However, because of the effect of population growth, the storage decreases more rapidly from 2030-2050 compared to the reference scenario, whereas the scenario E2 experiencing the largest decrease due to the increase of domestic water use (Figure 10a). Regarding climate change scenarios RCP4.5 and RCP8.5 (Figure 10b) the reduction of the groundwater storage is larger compared to the previous scenarios. This is directly due to the projected change in the precipitation for both scenarios causing a change in groundwater recharge and storage. Even though the drought events are predicted in both climate scenarios, some wet years can be observed in scenario RCP4.5, especially in 2018 and 2023, where the amount of groundwater storage exceeds that for initial storage. The most important rapid decrease of groundwater storage 
starts from June 2031 and ends in March 2038 for the RCP4.5 scenario, while in the RCP8.5 scenario, it begins from January 2032 and stops in March 2040.

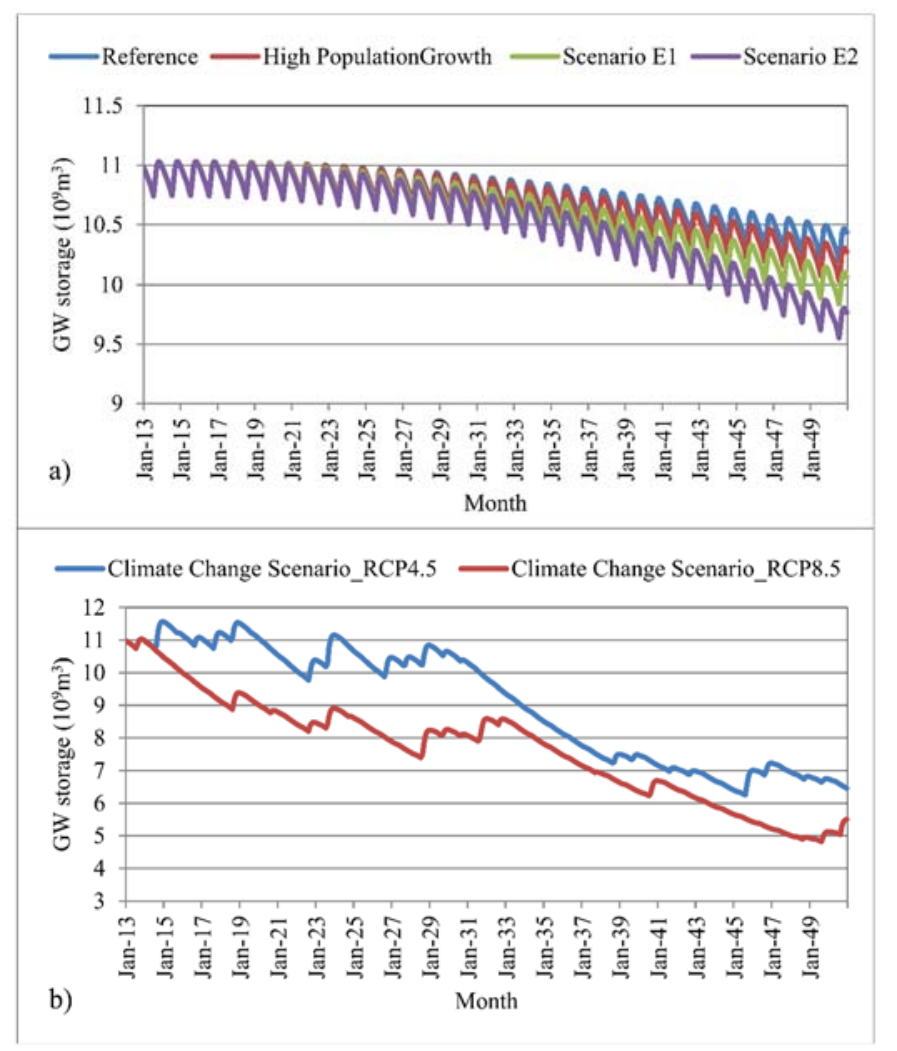

Figure 10. Development of the groundwater storage in billion cubic meters $\left(10^{9} \mathrm{~m}^{3}\right)$ for different scenarios (a) reference, population growth, socio-economic E1 and E2 and (b) climate change RCP4.5 and RCP8.5. Note the differences in the y-axes in both figures.

\section{Conclusions}

WEAP was applied to evaluate the impact of climate change and population growth on groundwater resources of the Klela basin. The overall results show that groundwater storage is decreasing mainly due to climate change effect and human activities. Groundwater recharge estimations using the Thornthwaite model reveal an important decrease in both climate scenarios, RCP4.5 and RCP8.5, especially in the 2030s. This decrease in recharge rate is higher in climate change scenario RCP8.5 than in RCP4.5. As a consequence, groundwater storage decreases significantly, especially in the 2030s. Because of population growth and socio-economic development, groundwater storage reduces over time but this reduction is less than that provoked by climate change effects. Groundwater recharge as well as storage is decreasing over time. Recharge declined by approximatively $49 \%$ and stored groundwater by $24 \%$ over the study period. The primary cause of depletion of groundwater resources is due to higher variability in precipitation projected by the scenarios. The models are actually predicting a drought in this area in 2031-2035 for RCP4.5.

This study concludes that groundwater resources are consequently affected by climate change and population growth. These results are important for decision makers to plan adaptation strategies although they are impacted by uncertainties caused by the models as well as by the observed input data. Especially, two years of measurements for climate data are rather short, therefore, a longer period of monitoring would be helpful for obtaining better results in terms of prediction. 
One of the possible adaptation strategies can be the artificial recharge technique in which surface discharge is used to raise groundwater storage. Nethertheless, this will impact water resources availability for downstream.

Acknowledgments: This work was supported by the German Federal Ministry of Education and Research (BMBF) under Grant No. 01LG1202E of the WASCAL project, which is available online at www.wascal.org. Also, we thank ENI-ABT of Bamako for their financial support.

Author Contributions: Adama Toure was responsible for this current research article in the framework of his Ph.D. program and initially wrote the manuscript. Bernd Diekkrüger directed the study by helping to interpret the results and to improve the quality of the manuscript. Adama Mariko helped to collect field data and manuscript correction. Abdoulaye Salim Cissé supported the development of the manuscript.

Conflicts of Interest: The authors declare no conflict of interest.

\section{References}

1. Comodi, G.; Cioccolanti, L.; Palpacelli, S.; Tazioli, A.; Nanni, T. Distributed generation and water production: A study for a region in central Italy. Desalin. Water Treat. 2011, 31, 218-225. [CrossRef]

2. Heath, R.C. Basic Ground-Water Hydrology, U.S. Geological Survey Water-Supply Paper 2220, 1983, 86p. Available online: https:/ / pubs.er.usgs.gov/djvu/WSP/wsp_2220.pdf (accessed on 22 June 2017).

3. Mahé, G.; Olivry, J.C.; Dessouassi, R.; Orange, D.; Bamba, F.; Servat, E. Relations eaux de surface-eaux souterraines d'une rivière tropicale au Mali. Surf. Geosci. 2000, 330, 689-692. [CrossRef]

4. Bricquet, J.P.; Bamba, F.; Mahe, G.; Toure, M.; Olivry, J.C. Évolution récente des ressources en eau de l'Afrique atlantique. Rev. Sci. Eau 1997, 10, 321. [CrossRef]

5. Roudier, P.; Mahé, G. Study of water stress and droughts with indicators using daily data on the Bani river (Niger basin, Mali). Int. J. Climatol. 2010, 30, 1689-1705. [CrossRef]

6. Toure, A.; Diekkrüger, B.; Mariko, A. Impact of Climate Change on Groundwater Resources in the Klela Basin, Southern Mali. Hydrology 2016, 3, 17. [CrossRef]

7. Cervi, F.; Corsini, A.; Doveri, M.; Mussi, M.; Ronchetti, F.; Tazioli, A. Characterizing the Recharge of Fractured Aquifers: A Case Study in a Flysch Rock Mass of the Northern Apennines (Italy). In Engineering Geology for Society and Territory—Volume 3; Lollino, G., Arattano, M., Rinaldi, M., Giustolisi, O., Marechal, J.-C., Grant, G.E., Eds.; Springer International Publishing: Cham, Switzerland, 2015; pp. 563-567.

8. Mussi, M.; Nanni, T.; Tazioli, A.; Vivalda, P.M. The Mt Conero Limestone Ridge: The contribution of stable isotopes in the identification of the recharge area of aquifers. Ital. J. Geosci. 2016. [CrossRef]

9. Aquilanti, L.; Clementi, F.; Nanni, T.; Palpacelli, S.; Tazioli, A.; Vivalda, P.M. DNA and fluorescein tracer tests to study the recharge, groundwater flowpath and hydraulic contact of aquifers in the Umbria-Marche limestone ridge (central Apennines, Italy). Environ. Earth Sci. 2016, 75. [CrossRef]

10. USAID. Plan de Sécurité Alimentaire Commune Rurale de Klela; Commissariat de la Sécurité Alimentaire (CSA); Commune Rurale de Kléla: Kléla, Republique du Mali, 2006.

11. McCabe, G.J.; Markstrom, S.L. A Monthly Water-Balance Model Driven by a Graphical User Interface. U.S. Geological Survey 2007, Open File Report 2007-1088, 6p. Available online: https:/ /pubs.usgs.gov/of/ 2007/1088/pdf/of07-1088_508.pdf (accessed on 11 August 2016).

12. SEI. WEAP: Water Evaluation and Planning System, User Guide for WEAP21; Stockholm Environment Institute: Boston, MA, USA, 2001.

13. Rosenzweig, C.; Strzepek, K.M.; Major, D.C.; Iglesias, A.; Yates, D.N.; McCluskey, A.; Hillel, D. Water resources for agriculture in a changing climate: International case studies. Glob. Environ. Chang. 2004, 14, 345-360. [CrossRef]

14. Yates, D.; Sieber, J.; Purkey, D.; Huber-Lee, A. WEAP21-A Demand-, Priority-, and Preference-Driven Water Planning Model. Int. Water Resour. Assoc. 2005, 30, 487-500. [CrossRef]

15. Haddad, M.; Jayousi, A.; Hantash, S.A. Applicability of WEAP as water management decision support system tool on localized area of watershed scales: Tulkarem District in Palestine as case study. Presented at the Eleventh International Water Technology Conference-IWTC11 2007, Sharm El-Sheikh, Egypt, 15-18 March 2007.

16. McCartney, M.P.; Arranz, R. Evaluation of Historic, Current and Future Water Demand in the Olifants River Catchment, South Africa; International Water Management Institute: Colombo, Sri Lanka, 2007. 
17. Hoff, H.; Bonzi, C.; Joyce, B.; Tielbörger, K. A Water Resources Planning Tool for the Jordan River Basin. Water 2011, 3, 718-736. [CrossRef]

18. Nayak, P.C.; Wardlaw, R.; Kharya, A.K. Water balance approach to study the effect of climate change on groundwater storage for Sirhind command area in India. Int. J. River Basin Manag. 2015, 13, $243-261$. [CrossRef]

19. SEI. WEAP Tutorial: A Collection of Stand-Alone Modules to Aid in Learning the WEAP Software; Stockholm Environment Institute: Stockholm, Sweden, 2015.

20. Traore, S.M.; Doumbia, A.G.; Traore, V.; Tolno, D.F. 4ème Recensement Général de la Population et de L'habitat du Mali (rgph-2009): Etat et Structure de la Population; Institut National de la Statistique (INSTAT): Bamako, Mali, 2011.

21. Traore, M.; Sissoko, Y. Les Institutions du Marché du Travail Face aux défis du Développement le cas du Mali; BIT: Genève, Switzerland, 2010.

22. Keïta, S.; Konaté, F.O. Le Mali et sa Population, in Questions de Population au Mali; UNFPA: New York, NY, USA, 2003; pp. 11-64.

23. Ozturk, T.; Altinsoy, H.; Türkeș, M.; Kurnaz, M. Simulation of temperature and precipitation climatology for the Central Asia CORDEX domain using RegCM 4.0. Clim. Res. 2012, 52, 63-76. [CrossRef]

24. Evans, J.P. CORDEX-An international climate downscaling initiative. Presented at the 19th International Congress on Modelling and Simulation, Perth, Australia, 26-28 May 2011; pp. 2705-2711.

25. Wayne, G.P. The Beginner's Guide to Representative Concentration Pathways. Skeptical Science. 2013. Available online: https:/ /skepticalscience.com/docs/RCP_Guide.pdf (accessed on 12 November 2015).

26. Van Vuuren, D.P.; Edmonds, J.; Kainuma, M.; Riahi, K.; Thomson, A.; Hibbard, K.; Hurtt, G.C.; Kram, T.; Krey, V.; Lamarque, J.-F.; et al. The representative concentration pathways: An overview. Clim. Chang. 2011, 109, 5-31. [CrossRef]

27. Moss, R.; Babiker, M.; Brinkman, S.; Calvo, E.; Carter, T.; Edmonds, J.; Elgizouli, I.; Emori, S.; Erda, L.; Hibbard, K.; et al. Towards New Scenarios for Analysis of Emissions, Climate Change, Impacts, and Response Strategies, Intergovernmental Panel on Climate Change 2008, Geneva. Available online: https:/ / www.ipcc.ch/pdf/supporting-material/expert-meeting-ts-scenarios.pdf (accessed on 12 November 2015).

28. Thomson, A.M.; Calvin, K.V.; Smith, S.J.; Kyle, G.P.; Volke, A.; Patel, P.; Delgado-Arias, S.; Bond-Lamberty, B.; Wise, M.A.; Clarke, L.E.; et al. RCP4.5: A pathway for stabilization of radiative forcing by 2100. Clim. Chang. 2011, 109, 77-94. [CrossRef]

29. Meinshausen, M.; Smith, S.J.; Calvin, K.; Daniel, J.S.; Kainuma, M.L.T.; Lamarque, J.-F.; Matsumoto, K.; Montzka, S.A.; Raper, S.C.B.; Riahi, K.; et al. The RCP greenhouse gas concentrations and their extensions from 1765 to 2300. Clim. Chang. 2011, 109, 213-241. [CrossRef]

30. Riahi, K.; Rao, S.; Krey, V.; Cho, C.; Chirkov, V.; Fischer, G.; Kindermann, G.; Nakicenovic, N.; Rafaj, P. RCP 8.5-A scenario of comparatively high greenhouse gas emissions. Clim. Chang. 2011, 109, 33-57. [CrossRef]

31. Lamarque, J.-F.; Kyle, G.P.; Meinshausen, M.; Riahi, K.; Smith, S.J.; van Vuuren, D.P.; Conley, A.J.; Vitt, F. Global and regional evolution of short-lived radiatively-active gases and aerosols in the Representative Concentration Pathways. Clim. Chang. 2011, 109, 191-212. [CrossRef]

32. N’Djim, H.; Doumbia, B. Population and Water Issues: Case Study Mali; American Association for the Advancement of Science: Washington, DC, USA, 1998.

33. WHO (Ed.) The Right to Water; WHO: Geneva, Switzerland, 2003.

34. WWAP. Rapport National sur la Mise en Valeur des Ressources en Eau: Mali. UN-Water/WWAP/2006/10. Bamako, Mali, 2006. Available online: http://unesdoc.unesco.org/images/0014/001472/147267f.pdf (accessed on 12 November 2015).

35. Diakité, L.; Zida, M. Étude Diagnostique de la Filière Pomme de Terre Dans Trois Pays de L'Afrique de L'ouest: Cas du Mali; CILSS-Institut du Sahel: Bamako, Mali, 2003.

(C) 2017 by the authors. Licensee MDPI, Basel, Switzerland. This article is an open access article distributed under the terms and conditions of the Creative Commons Attribution (CC BY) license (http:/ / creativecommons.org/licenses/by/4.0/). 